\title{
POWSTANIE KRAKOWSKIEJ WYŻSZEJ SZKOŁY PEDAGOGICZNEJ I PRÓBA JEJ PRZYŁĄCZENIA DO UNIWERSYTETU JAGIELLOŃSKIEGO W 1956 ROKU
}

\author{
Wanda Łuczak (D) http://orcid.org/0000-0002-7302-0155
}

\author{
ABSTRACT \\ ESTABLISHMENT OF THE NATIONAL HIGHER TEACHER TRAINING \\ COLLEGE (WSP) AND AN ATTEMPT TO MERGE IT \\ WITH THE JAGIELLONIAN UNIVERSITY IN 1956
}

\begin{abstract}
After the Second World War, the Jagiellonian University lost its autonomy and the state authorities destroyed its structures by separating the departments and creating new universities out of them. Independently, in 1946, the National Higher Teacher Training College in Krakow was established. In 1954, it received the right to run a master's course. The quality of education in WSP was assessed negatively by the Jagiellonian University. In turn, the WSP authoritiesclaimed that their school provided better training for future teachers. At the beginning of the 1950s, some reservations were voiced as to the grounds for the existence of higher teacher training schools due to overlaps with the university curriculum. In 1956, the state authorities decided to close some of these colleges. WSP was to be merged with the Jagiellonian University. A meeting was organized at the Jagiellonian University in April 1956, where representatives of the Ministry of Higher Education, the Jagiellonian University and WSP discussed the merger. However, the meeting didn't yield the expected results due to the firm objection on the part of WSP. The opportunity to strengthen the Jagiellonian University's position by merging with WSP was ultimately lost.
\end{abstract}

Keywords: colleges, Polish People's Republic, Jagiellonian University, National Higher Teacher Training College.

Słowa kluczowe: szkoły wyższe, Polska Rzeczpospolita Ludowa, Uniwersytet Jagielloński, Wyższa Szkoła Pedagogiczna.

Uniwersytet Jagielloński po zakończeniu II wojny światowej musiał zmierzyć się z zupełnie nową sytuacją. W czasie okupacji uczelnia nie mogła funkcjonować w nikłej części rekompensowało to podziemne nauczanie, prowadzone przez wielu 
wykładowców UJ. Wojna przyniosła stratę znakomitych nauczycieli akademickich i ta uszczuplona kadra stanęła przed ogromnym wyzwaniem, jakie niosło z sobą wkroczenie wojsk sowieckich do Polski i wprowadzenie rządów komunistycznych. W roku 1945, zaraz po przetoczeniu się przez Polskę działań wojennych, w kolejnych miastach wznawiały działalność szkoły wyższe. Pracownicy naukowi wracali do pracy i w miarę możliwości rozpoczynali zajęcia ze studentami. Władze komunistyczne początkowo nie starały się za bardzo ingerować w funkcjonowanie uczelni. Był to czas wzajemnego poznawania się; władza ludowa nie podejmowała drastycznych działań do czasu aż sytuacja w kraju ustabilizuje się i „siły reakcyjne” zostaną wyeliminowane. Wszystko toczyło się starym trybem w zgodzie z przedwojennymi przepisami prawa. Stan ten był jednak tylko przejściowy. Metodą drobnych kroków, wprowadzając kolejne zmiany w regulacjach prawnych, dokonywano stopniowego podporządkowywania uczelni. Polska Partia Robotnicza (PPR) była zdecydowana wpływać na sytuację w szkolnictwie wyższym. Powołano do życia cztery nowe uniwersytety ${ }^{1}$.

Dzieje uczelni wyższych w Polsce po II wojnie światowej doczekały się wielu opracowań. Do nich w pierwszej kolejności należy Historia nauki polskiej (tom X obejmuje lata 1944-1989), która w trzech częściach obszernie pokazuje przemiany szkolnictwa wyższego pod rządami władz komunistycznych ${ }^{2}$. Przełomowemu okresowi 1944-1956 poświęcone są opracowania Janiny Chodakowskiej, Bolesława Krasiewicza, Piotra Hübnera oraz wielu innych badaczy, pokazujące początki rządów władz komunistycznych ${ }^{3}$. Cenne są pozycje poświęcone historii szkolnictwa pedagogicznego, w tym przede wszystkim opracowania Romualda Grzybowskiego ${ }^{4}$. Historia poszczególnych uczelni w latach PRL, także Uniwersytetu Jagiellońskiego i Wyższej Szkoły Pedagogicznej, była przedmiotem badań, choć wciąż jeszcze wiele jej aspektów czeka na zainteresowanie. Jednym z nich są powojenne dzieje Uniwersytetu Jagiellońskiego - najstarszej uczelni w Polsce - oraz powstanie Wyższej Szkoły Pedagogicznej w Krakowie - szkoły nowego typu, spełniającej socjalistyczne wymogi kształcenia. Ich wzajemne relacje w pierwszych powojennych latach pokazują,

${ }^{1}$ Nowe uniwersytety powstały w Lublinie, Łodzi, Toruniu. Na bazie niemieckiej uczelni powstał uniwersytet we Wrocławiu, stare to: Kraków, Warszawa i Poznań.

${ }^{2}$ Historia nauki polskiej, t. X, 1944-1989, cz. 1: Warunki rozwoju nauki polskiej, państwo i spoteczeństwo, cz. 2: Instytucje, cz. 3: Idee i praktyka, red. L. Zasztow t, J. Schiller-Walicka, Warszawa 2015.

${ }^{3}$ J. Chodakowska, Rozwój szkolnictwa wyższego w Polsce Ludowej w latach 1944-1951, Wrocław 1981; J. Jarowiecki, Kształcenie nauczycieli w wyższych szkołach pedagogicznych, WarszawaKraków 1967; B. Krasiewicz, Odbudowa szkolnictwa wyższego w Polsce Ludowej w latach 19441948, Wrocław 1976; J.K. Szłapczyński, Zarzą szkoła wyższa w Polsce Ludowej, Warszawa 1968; J. Tymowski, Organizacja szkolnictwa wyższego w Polsce, Warszawa 1980; T.P. Rutkowski, Nauki historyczne w Polsce 1944-1970. Zagadnienia polityczne i organizacyjne, Warszawa 2007; P. Hübner, Polityka naukowa w Polsce w latach 1944-1953. Geneza systemu, Wrocław 1992.

${ }^{4}$ Oświata, wychowanie, kultura fizyczna w rzeczywistości społeczno-politycznej Polski Ludowej (1945-1989), red. R. Grzybowski, Torun 2004; R. Grzybowski, Wyższe szkoły pedagogiczne w Polsce w latach 1946-1956, Toruń 2010. 
jak władze komunistyczne próbowały kształtować rzeczywistość szkolnictwa wyższego według nowych wzorców ${ }^{5}$.

Mocnym sygnałem nadchodzących zmian był dekret z 28 października 1947 roku o organizacji szkolnictwa wyższego: szkoły wyższe pozbawione zostały autonomii, wybór władz uczelni został scedowany na ministra oświaty w przypadku szkół zawodowych, a prezydenta w przypadku szkół akademickich ${ }^{6}$. Minister otrzymał szerokie kompetencje, do których należało między innymi dokonywanie zmian w strukturze organizacyjnej szkoły, mianowanie rektora w szkołach zawodowych, mianowanie dyrektora administracyjnego, zatwierdzanie budżetu. Rektor szkoły akademickiej czyli między innymi uniwersytetu - miał być powoływany przez prezydenta na trzy lata spośród kandydatów wybranych na ogólnym zebraniu pracowników uczelni po zasięgnięciu opinii Rady Głównej ds. Nauki i Szkolnictwa Wyższego. Ustalono, że przez pierwszych pięć lat kandydatów przedstawia Rada Główna, nie doszło natomiast nigdy do wyłaniania kandydatów przez zebranie pracowników uczelni, dekret bowiem przestał działać już w 1951 roku. Organami szkoły akademickiej byli rektor i prorektor, senat, zebranie ogólne, dziekani i prodziekani, rady wydziałowe, dyrektor administracyjny. Nie zapisano, że rektor kieruje szkołą - miał on tylko reprezentować szkołę na zewnątrz, pełnić funkcję przewodniczącego senatu i zebrania ogólnego. Senat był ,najwyższym organem i rzecznikiem potrzeb szkoły oraz opiekunem młodzieży studiującej”. Nowym organem, powoływanym przez ministra oświaty, był dyrektor administracyjny, który odpowiadać miał za realizację budżetu. Istotę stanowił zapis, że w okresie przejściowym profesorowie i docenci etatowi mogą być zwalniani i przenoszeni do innych szkó $1^{7}$. Na bazie tych przepisów w roku akademickim 1948/1949 nie doszło już do autonomicznych wyborów rektora UJ: „Z nominacji rządowej został nim Teodor Marchlewski, profesor zajmujący się hodowlą zwierząt i genetyką"8.

${ }_{5}^{5}$ A.K. Banach, J. Dybiec, K. Stopka, Dzieje Uniwersytetu Jagiellońskiego, Kraków 2000; Wyższa Szkoła Pedagogiczna w Krakowie w pierwszym piętnastoleciu rozwoju 1946-1961, red. M. Tyrowicz [et al.], Kraków 1965. Przyczynkiem do poznania historii powojennej UJ jest praca doktorska W. Łuczak, Między autonomia a zależnością. Przygotowania do obchodów jubileuszu 600-lecia Uniwersytetu Jagiellońskiego, obroniona na Wydziale Historycznym UJ w 2017 r.

${ }^{6}$ Dekret Rady Ministrów z dnia 28 X 1947 r. o organizacji nauki i szkolnictwa wyższego (Dz.U. 1947, nr 66, poz. 415). Obszernie na temat tego aktu prawnego zob. J.K. Szłapczyński, op. cit., s. 21 oraz J. Tymowski, op. cit., s. 50.

7 Jak napisał Bolesław Krasiewicz, ,[...] dekret nie uszczuplał uprawnień autonomicznych władz akademickich, o ile działalność samorządu uczelnianego nie wchodziła w kolizję z ogólnym kierunkiem rozwojowym narodu i państwa polskiego [...]. Ogólnie rzecz biorąc, dekret stwarzał poważne możliwości ideologicznego i politycznego oddziaływania na szkolnictwo wyższe, umożliwił wprowadzenie nowych pracowników w miejsce sił konserwatywnych, pozwalał władzom państwowym na ściślejszą kontrolę działalności władz samorządowych uczelni wyższych, umożliwiał dokonywanie głębszych zmian w składzie społecznym młodzieży akademickiej”. B. Krasiewicz, op. cit., s. 333 oraz 336.

${ }^{8}$ S. Grzybowski, Wspomnienia, Kraków 1999, s. 624. Mianowany przez władze rektor Teodor Marchlewski, syn Leona, profesora UJ, bratanek Juliana, członek PPR (od 1947 r.), potem PZPR, poseł na Sejm PRL w latach 1952-1956, zarządzał uczelnią przez osiem lat. Stefan Grzybowski tak charakteryzował rektora: „Teodor Marchlewski wstąpił do PPR i korzystał z owej koneksji rodzinnej oraz popierał wszelkie zmiany, jakie wprowadzała PZPR i władze. Człowiek chory, kaleki, fizycznie niedołężny, nie 
Władze komunistyczne umocniły się i w pełni kontrolowały sytuację w kraju. W życie weszła Ustawa o szkolnictwie wyższym i pracownikach nauki z dnia 15 grudnia 1951 roku, która w zasadzie zlikwidowała samorządność uczelni甲. Cały system zarządzania oparto na zasadzie jednoosobowej odpowiedzialności i kierownictwa - zarząd nad szkołami objął minister szkolnictwa wyższego. Miał on uprawnienia do samodzielnego powoływania, likwidowania i przekształcania wydziałów, katedr i innych komórek organizacyjnych szkoły. Ustalał również plany studiów, programy i regulaminy. Ostatecznie zniesiono wybieralność władz uczelni. Rektora powoływał minister, a prorektorów, dziekanów i prodziekanów oraz kierowników innych komórek organizacyjnych - minister na wniosek rektora. Rektor miał kierować działalnością uczelni i być odpowiedzialny za wykonanie jej zadań. Senat miał zajmować się sprawami przekazanymi przez rektora. Wprowadzono stanowisko zastępcy rektora do spraw administracyjnych (w miejsce dyrektora), którego powoływał minister na wniosek rektora. Należy zaznaczyć, że ustawa wprowadzała radzieckie wzorce do szkolnictwa polskiego: ustalała, że niższym stopniem naukowym będzie kandydat nauk, a wyższym doktor nauk.

Kolejnym ciosem dla autonomiczności uczelni było rozbicie ich struktury przez wydzielanie kolejnych wydziałów i tworzenie z nich samodzielnych uczelni:

Zreorganizowano szkolnictwo wyższe według wzorów radzieckich: wydziały medyczne i farmaceutyczne wydzielono $\mathrm{z}$ uniwersytetów i przekształcono $\mathrm{w}$ akademie medyczne podporządkowane Ministerstwu Zdrowia, wydziały wychowania fizycznego stały się samodzielnymi wyższymi szkołami podlegającymi Głównemu Komitetowi Kultury Fizycznej, wyższe szkoły artystyczne przeszły do Ministerstwa Kultury. [...] Następnie wydzielono z uniwersytetów wydziały rolne, tworząc z nich samodzielne wyższe szkoły rolnicze; w 1954 roku przekształcono wydziały teologiczne w oddzielne akademie teologiczne ${ }^{10}$.

Te zmiany wraz z zapisem w ustawie, że szkoły wyższe mają kształcić i wychowywać inteligencję ludową w duchu ofiarnej służby ojczyźnie, walki o pokój i socjalizm, przy jednoczesnym wskazaniu, że pierwszym zadaniem jest przygotowanie pracowników o najwyższym poziomie kwalifikacji zawodowych jasno określało priorytety władzy $^{11}$. Ówczesny minister szkolnictwa wyższego Adam Rapacki sumował:

[...] celem było przekształcenie szkoły wyższej w szkołę typu socjalistycznego, oparcie pracy szkoły wyższej w Polsce na następujących zasadach: po pierwsze, na jedności nauki, nauczania i wychowania na podstawie materializmu dialektycznego, w celu przygotowania kadr socjalistycznej inteligencji i rozwinięcia badań naukowych dla potrzeb socjalistycznego przeobrażenia społeczeństwa; po drugie na socjalistycznych zespołowych metodach, stylu i organizacji pracy kadr naukowych i młodzieży ${ }^{12}$.

zrobił nic dla Uniwersytetu, oddał Akademii Medycznej całe Collegium Nowodworskiego, wprowadzał wielu partyjnych pracowników naukowych i administracyjnych". S. Grzybowski, Wspomnienia, s. 625; oraz Polski Stownik Biograficzny, t. XIX, red. E. Rostworowski, Wrocław [etc.] 1974, s. 547-549.

${ }^{9}$ Ustawa z dnia 15 XII 1951 r. o szkolnictwie wyższym i pracownikach nauki (Dz.U. 1952, nr 6, poz. 38); J.K. Szłapczyński, op. cit., s. 30; oraz J. Tymowski, op. cit., s. 61.

${ }_{10}$ J. Tymowski, op. cit., s. 59.

${ }^{11}$ Ustawa z dnia 15 XII 1951 r. ..., Dział I, art. 1.

12 Politechnika Warszawska, red. K. Kolbiński, Warszawa 1965, s. 135. 
Za rektoratu prof. Marchlewskiego UJ został okrojony: w roku 1949 zdecydowano, że wydziały lekarski i farmaceutyczny zostaną wydzielone $\mathrm{z}$ uniwersytetu i przekształcone w Akademię Medyczną podlegającą Ministerstwu Zdrowia ${ }^{13}$. W tym samym roku zlikwidowano Studium Spółdzielcze, a w następnym Studium Wychowania Fizycznego przejściowo włączono do Akademii Medycznej, aby ostatecznie przekształcić je w samodzielną uczelnię. Wydzielono z uniwersytetu także wydziały rolny i leśny, przekształcając je w samodzielną Wyższą Szkołę Rolniczą, a w 1954 roku usunięto Wydział Teologiczny: „W ten sposób uniwersytety straciły swój dotychczasowy charakter Universitas litterarum"14. Utrata przodującej pozycji wśród uczelni krakowskich - Uniwersytet bowiem stał się tylko jedną z kilkunastu uczelni w Krakowie - była bardzo bolesna ${ }^{15}$.

Jakie skutki przyniosło okrojenie uniwersytetów? Jak wspominał Jerzy Serczyk:

[...] z punktu widzenia władzy miało to co najmniej dwie zalety: 1 . Uniwersytety zostały zdegradowane w odczuciu społecznym do jednej z wielu kategorii szkół wyższych. Przyjęło się wtedy nazywanie ich w wystąpieniach oficjalnych ,uczelniami humanistycznymi” chociaż zachowały w swych strukturach wydziały przyrodnicze. W określeniu „humanistyczny” mieścił się pewien odczuwalny odcień pogardy dla umiejętności nie mających natychmiastowego praktycznego (,,produkcyjnego") zastosowania. Nie powiedziano tego nigdy expressis verbis, ale powstawało wrażenie, że uniwersytety nie są uczelniami tak ważnymi, jak same o sobie sądzą; jest dowodem wielkoduszności rządzących, że pozwala się na ich istnienie. Powinny być za to wdzięczne. 2. przez stworzenie stosunkowo znacznej liczby nowych uczelni nastąpiła atomizacja środowiska i wyraźne zmniejszenie potencjału intelektualnego uniwersytetów ${ }^{16}$.

W dalszej konsekwencji nastąpił dotkliwy spadek liczby studentów. W roku akademickim 1945/1946 studiowało na UJ 9413 osób, w kolejnym - 12643 (był to efekt napływu na uczelnię osób, które przed wojną nie dokończyły studiów lub nie zdążyły rozpocząć edukacji). W roku akademickim 1949/1950, po odpadnięciu wydziałów lekarskiego i farmaceutycznego oraz Studium Wychowania Fizycznego naukę rozpoczęło 10981 osób. W roku akademickim 1953/1954, po wyłączeniu wydziałów leśnego i rolnego - już tylko 3461 osób, a w kolejnym, po odłączeniu

${ }^{13}$ Rozporządzenie Rady Ministrów z dnia 24 X 1949 r. w sprawie założenia akademii lekarskich w Warszawie, Krakowie, Poznaniu, Lublinie, Łodzi i Wrocławiu (Dz.U. 1949, nr 58 poz. 450). Akademia Medyczna w Krakowie rozpoczęła działalność 1 I 1950 r., tym samym UJ opuszczało 674 pracowników, w tym 253 pracowników naukowych oraz 2460 studentów. Por. Sześćsetlecie medycyny krakowskiej. W sześćsetlecie Uniwersytetu Jagiellońskiego, t. 2: Historia katedr, red. nauk. L. Tochowicz [et al.], Kraków 1964, s. 714-715.

14 J. Tymowski, op. cit., s. 59.

${ }^{15}$ Przed II wojną światową w Krakowie funkcjonowały trzy uczelnie państwowe: Uniwersytet Jagielloński, Akademia Górnicza oraz Akademia Sztuk Pięknych oraz jedna prywatna: Akademia Handlowa. Zmiany, które nastąpiły w latach 50., spowodowały wzrost liczby uczelni do 11 . Były to: UJ, AGH, Akademia Medyczna, Państwowa Wyższa Szkoła Pedagogiczna (od 1952 r. Wyższa Szkoła Pedagogiczna), Politechnika Krakowska, Wyższa Szkoła Wychowania Fizycznego, Wyższa Szkoła Rolnicza, Akademia Ekonomiczna, Akademia Sztuk Pięknych, Państwowa Wyższa Szkoła Teatralna, Wyższa Szkoła Muzyczna.

${ }^{16}$ J. Serczyk, Uniwersytety polskie w latach stalinizmu (esej wspomnieniowy), „Czasy Nowożytne” 1999, t. VI, s. 240. 
Wydziału Teologicznego - 3324. W roku akademickim 1955/1956 studiowało na UJ 2951 osób. Spadek był więc znaczny, bo między rekordowym rokiem 1946/1947 a rokiem 1955/1956 wynosił prawie 10 tys. studentów ${ }^{17}$. Bolesław Drobner, zastępca rektora do spraw administracyjnych, w 1954 roku zauważał:

[...] daje się zauważyć lekceważenie Uniwersytetu Jagiellońskiego. Najstarsza Uczelnia jest stopniowo redukowana. Uniwersytet Warszawski pęcznieje, posiada w tej chwili, według składu 12 wydziałów, rośnie. Uniwersytet Jagielloński maleje, traci z roku na rok swój stan posiadania. Czy z pożytkiem dla nauki i poziomu nauczania? Dyskutant zaznacza, że mówił o tym ministrowi Golańskiemu - jednak żaden argument nie znajduje zrozumienia w Warszawie. Przy istniejących zadaniach Uniwersytetu następuje stałe redukowanie środków potrzebnych do wykonania tych zadań. W ten sposób Uczelnia traci pozycję po pozycji. Mimo oficjalnych zaprzeczeń fakty mówią wyraźnie, że tak jest ${ }^{18}$.

W 1946 roku Ministerstwo Oświaty powołało do życia Państwową Wyższą Szkołę Pedagogiczną w Krakowie (PWSP) ${ }^{19}$. Miała ona - w zamierzeniu władz - kształcić nauczycieli szkół powszechnych (podstawowych), których brak dotkliwie odczuwano po wojnie ${ }^{20}$. PWSP rozpoczęła działalność we wrześniu 1946 roku; powstała na bazie Państwowego Pedagogium, istniejącego w Krakowie w latach międzywojennych; przejęła jego budynki i studentów ${ }^{21}$. Na początku zorganizowano dwa kierunki studiów trzyletnich, na czele szkoły stał dyrektor. Podkreślano, że celem głównym jest kształcenie zawodowe nowych nauczycieli i dokształcanie już czynnych. W roku akademickim 1948/1949 rozpoczęło się przekształcanie szkoły w wyższą uczelnię: powołano rektora, dziekanów, zalążki wydziałów (w miejsce dotychczasowych

${ }^{17}$ Kronika Uniwersytetu Jagiellońskiego za lata akademickie 1945/1946-1955/1956, Kraków 1971, s. 132.

18 Archiwum Uniwersytetu Jagiellońskiego (dalej: AUJ), SIV SOg 2, Protokoły posiedzeń Senatu UJ z lat 1953-59. Protokół z posiedzenia poszerzonego Senatu Uniwersytetu Jagiellońskiego z 29 VI 1954 r.

19 Od 1952 r. Wyższa Szkoła Pedagogiczna, od 1999 r. Akademia Pedagogiczna, a od 2008 r. Uniwersytet Pedagogiczny.

${ }^{20}$ W 1946 r. powołano do życia cztery szkoły pedagogiczne: w Krakowie, Gdańsku, Łodzi i Katowicach (ta ostatnia po roku została wcielona do łódzkiej WSP), w kolejnych latach następne: w Warszawie, Wrocławiu (przeniesiona do Opola w 1954 r.), Katowicach (po raz drugi). Na początku 1956 r. liczba WSP ustaliła się na poziomie sześciu, podlegały one Ministerstwu Oświaty (inne szkoły wyższe Ministerstwu Szkolnictwa Wyższego). Należy tu wspomnieć, że uważa się, iż samo założenie krakowskiej PWSP było próbą osłabienia i podważenia roli Uniwersytetu Jagiellońskiego. Trudno się z tym zdaniem w pełni zgodzić: przy zakładaniu nie mogło być mowy o konkurencyjności, PWSP bowiem prowadziła studia trzyletnie stricte nauczycielskie, nakierowane na szkoły podstawowe, czyli zastępowała przedwojenne pedagogia. Zagrożenie pojawiło się później, kiedy uczelnia otrzymała prawo nadawania tytułów magisterskich i jej absolwenci zaczęli konkurować z absolwentami UJ. Por. A.K. Banach, J. Dybiec, K. Stopka, op. cit., s. 188.

${ }^{21}$ Państwowe Pedagogium zostało powołane w 1928 r. (wcześniej szkoła funkcjonowała jako Powszechne Kursy Pedagogiczne, a następnie Państwowe Kursy Nauczycielskie) i zajmowało się kształceniem nauczycieli szkół powszechnych. Nauka trwała dwa lata. Po wojnie reaktywowano je, traktując jednak jako formę przejściową i bazę do stworzenia nowego typu szkół pedagogicznych. Por. Państwowe Pedagogium i Szkoła Ćwiczeń w Krakowie. Z tradycji ksztatcenia nauczycieli, oprac. J. Krukowski, B. Morawska-Nowak, Kraków 2011, s. 17; R. Grzybowski, Geneza wyższych szkót pedagogicznych i ich rozwój organizacyjny w latach 1946-1949, „Biuletyn Historii Wychowania” 2000, nr 1-2, s. 38. 
sekcji ${ }^{22}$.W dalszym ciągu jednak nie zostało jasno określone, czym są szkoły pedagogiczne: uczelniami wyższymi, czy instytutami pedagogicznymi. Z czasem jednak zaczął zwyciężać pogląd, że będą to uczelnie wyższe kształcące nauczycieli zarówno szkół podstawowych, jak i średnich.

W 1954 roku uczelnia otrzymała prawo prowadzenia czteroletnich studiów magisterskich dziennych i pięcioletnich zaocznych ${ }^{23}$. „Reorganizacja upodobniała WSP w znacznej mierze do uniwersytetów: przyjęto szereg form organizacyjnych za uniwersytetami: powołano rektora, dziekanów, rady wydziałowe" ${ }^{24}$. WSP nie była uczelnią dużą; studia stacjonarne ukończyły w 1952 roku 153 osoby, w 1953 - 244, $1954-248,1955-72$, a w $1956-125^{25}$. W roku 1956, pod koniec pierwszego dziesięciolecia, liczba samodzielnych etatowych pracowników nauki wynosiła 34 osoby, a pomocniczych $-52^{26}$. Studiowały wówczas na uczelni 783 osoby na studiach dziennych oraz 616 na studiach zaocznych ${ }^{27}$.

Już wcześniej, bo w roku 1950, pojawiły się zastrzeżenia co do istnienia niektórych wyższych szkół pedagogicznych jako dublujących uniwersytecki program nauczania. Wskazywano, że uniwersytety bez trudu mogą wykształcić nauczycieli, zwiększając nacisk na przedmioty pedagogiczne, a WSP powinny istnieć jedynie w ośrodkach pozbawionych szkół wyższych ${ }^{28}$. Głosy o możliwości likwidacji WSP nasiliły się pod koniec okresu stalinowskiego:

Polityka Ministerstwa Oświaty z lat 1949-1955, prowadząca do konfrontacji WSP z uniwersytetami, doprowadziła do tego, że wraz z odchodzeniem Polski od stalinowskiego modelu państwa i obowiązującej w nim organizacji szkolnictwa wyższego pojawiły się głosy o potrzebie likwidacji wyższych szkół pedagogicznych. Okazją do tego pod koniec roku 1955 stały się zaskakująco dobre warunki kadrowe szkolnictwa średniego i wynikająca stąd groźba „nadprodukcji” nauczycieli z wyższym wykształceniem ${ }^{29}$.

Do tego doszły naciski, by młodzież wybierała zasadnicze szkoły zawodowe, a nie licea ogólnokształcące, co skutkowało mniejszym zapotrzebowaniem na nauczycieli.

Debata na temat przyszłości szkół pedagogicznych odbywała się na łamach czasopism, między innymi „Życia Szkoły Wyższej”. Przedstawiciel WSP w Warszawie, rektor Stefan Kałuski, bronił istnienia szkół pedagogicznych, wysuwając argument, że uczelnie idą w kierunku specjalizacji: z uniwersytetów wyodrębniły się szkoły zawodowe (medyczne i rolnicze), tak też powinno być z WSP jako

${ }^{22}$ Dziesięciolecie Wyższej Szkoły Pedagogicznej w Krakowie 1946-1956, red. W. Danek, Kraków 1957, s. 18.

${ }^{23}$ Ibidem, s. 26.

${ }^{24}$ J. Jarowiecki, op. cit., s. 4.

${ }^{25}$ Z. Tabaka, Z dziejów Wyższej Szkoty Pedagogicznej w Krakowie (1946-1961) [w:] Ksztatcenie nauczycieli w Wyższej Szkole Pedagogicznej (Konferencja naukowa ku uczczeniu 15-lecia Wyższej Szkoły Pedagogicznej w Krakowie 1946-1961), red. W. Gałecki, Kraków 1962, s. 181.

${ }^{26}$ Ibidem, s. 167.

27 Dziesięciolecie Wyższej Szkoły Pedagogicznej..., s. 32, 34.

${ }^{28}$ R. Grzybowski, Wyższe szkoty..., s. 92.

${ }^{29}$ Ibidem, s. 130. 
szkołami pedagogicznymi. Podkreślał, że taka forma kształcenia nauczycieli obowiązuje w ZSRR ${ }^{30}$. Tymczasem w „Życiu Szkoły Wyższej” relacjonowano zmiany w szkolnictwie ZSRR, gdzie w 1955 roku na uniwersytetach wprowadzono przedmioty pedagogiczne, w związku ze zwrotem „frontem ku szkole średniej”31. Takie informacje nie mogły pozostać bez odpowiedzi - zapowiedź zmian na polskich uczelniach pojawiła się w wywiadzie z wiceminister szkolnictwa wyższego Eugenią Krassowską, która stwierdziła: „Trudności rozwoju uniwersytetów potęgował brak precyzji w podziale zadań między nimi a wyższymi szkołami pedagogicznymi” i zapowiadała pedagogizację studiów uniwersyteckich ${ }^{32}$. Ryszard Wroczyński z Uniwersytetu Warszawskiego opowiadał się zdecydowanie za kształceniem nauczycieli na uniwersytetach, zakładając zwiększenie nacisku tychże na przedmioty pedagogiczne ${ }^{33}$. Debata toczyła się także na łamach „Głosu Nauczycielskiego”, który przygotował ankietę skierowaną do nauczycieli. Pytano w niej między innymi o to, czy nauczycieli klas VIII-XI kształcić powinny uniwersytety czy wyższe szkoły pedagogiczne. Zdecydowana większość respondentów opowiedziała się za uniwersytetami (prawie $22 \%$, za WSP $-11 \%)^{34}$. Na łamach tego pisma wypowiedział się też Kazimierz Wojciechowski, dyrektor departamentu w Ministerstwie Oświaty, który potwierdzał, że kolejne lata mogą przynieść nadprodukcję nauczycieli. Dodawał, że WSP są potrzebne, aczkolwiek w miastach, w których znajdują się uniwersytety, nie ma sensu utrzymywania dwutorowości kształcenia, gdy można lepiej wykorzystać kadry naukowe i bazę lokalową 35 .

$\mathrm{Na}$ Uniwersytecie Jagiellońskim krytycznie oceniano kształcenie w WSP i rywalizację absolwentów obu uczelni. W 1955 roku podczas posiedzenia Senatu UJ prof. Mieczysław Brożek zwrócił uwagę:

Wydziały oświaty WRN [Wojewódzkich Rad Narodowych - W.Ł.] podległe Ministerstwu Oświaty faworyzują absolwentów z PWSP (jako uczelni podległych również Ministerstwu Oświaty), przydzielają im nauczanie w liceach, natomiast absolwentów z Uniwersytetów „wpychają" do szkół podstawowych - jakkolwiek poziom absolwentów wskazuje na to, że powinno być odwrotnie. Jest to przejrzysta polityka odciągania młodzieży, wstępującej na uczelnie wyższe, od uniwersytetów ${ }^{36}$.

${ }^{30}$ Radzieckie uczelnie miały charakter wyższych szkół zawodowych, których zadaniem było przygotowanie pracowników dla poszczególnych dziedzin gospodarki. Obowiązywały plany przyjęć kandydatów na studia, na specjalizację zawodową oraz nakazy pracy. Por. T. Wiloch, Radziecki system oświatowo-wychowawczy, Warszawa 1962, s. 133; S. Kału ski, W sprawie systemu ksztatcenia nauczycieli szkót średnich, „Życie Szkoły Wyższej” 1956, nr 1, s. 34-35.

${ }^{31}$ Absolwenci uniwersytetów - nauczycielami szkót średnich, „Życie Szkoły Wyższej” 1956, nr 2, s. 77-78.

${ }^{32}$ Szkolnictwo wyższe u progu planu 5-letniego, „Życie Szkoły Wyższej” 1956, nr 2, s. 7.

${ }_{33}$ R. Wroczyński, Uniwersytet czy wyższe szkoły pedagogiczne, „Życie Szkoły Wyższej” 1956, nr 3, s. $42-46$.

34 „Głos Nauczycielski”, 11 III 1956, nr 11, s. 1.

35 Problem WSP $i$ uniwersytetów, „Głos Nauczycielski”, 1 IV 1956, nr 14, s. 1.

${ }^{36}$ AUJ, S IV SO g 2, Protokoły posiedzeń Senatu UJ z lat 1953-1959, Protokół z posiedzenia Senatu Uniwersytetu Jagiellońskiego z 10 IV 1955 r. 
Prorektor UJ prof. Kazimierz Lepszy nie dawał wiary w wysoki poziom nauczania absolwentów WSP, z kolei prof. Jan Moszew przyznał: „,[..] daje się wyczuć współzawodnictwo pomiędzy Uniwersytetami i Wyższymi Szkołami Pedagogicznymi - przy czym absolwenci uniwersyteccy są wyraźnie lepsi”"37. Jako że w grudniu 1955 roku planowana była ogólnopolska konferencja pedagogiczna uniwersytetów właśnie w Krakowie, władze UJ dyskutowały nad sprawą pedagogizacji. Skłaniano się ku poglądowi, że liczne kursy nauczycielskie i WSP, które powstały w wyniku potrzeby chwili zaraz po wojnie, były jedynie formą przejściową. Obserwowano też nastroje konfrontacyjne między uniwersytetami a WSP, co przejawiało się w rozmaitych artykułach prasowych. Profesor Zygmunt Mysłakowski (profesor UJ, a zarazem rektor WSP w Krakowie), który był jednym z organizatorów konferencji, przypominał, że wielu naukowców na UJ sprawę przygotowania nauczycielskiego traktuje po macoszemu, uważając UJ za „fabrykę uczonych”38. Jednocześnie Senat UJ sygnalizował, że wobec głosów o konieczności likwidacji dwutorowości nauczania należy pomyśleć o zmodyfikowaniu studiów uniwersyteckich pod kątem ich pedagogizacji. Potrzeba taka była już paląca, tym bardziej że w 1952 roku na żądanie władz zlikwidowane zostało Studium Pedagogiczne, które prowadziło zajęcia przygotowujące studentów różnych kierunków do podjęcia pracy w szkolnictwie średnim ${ }^{39}$.

Z kolei krakowska WSP dowodziła, że lepiej przygotowuje kadry nauczycielskie:

W ciągu 9 lat wypracowaliśmy metody kształcenia nauczycieli. Strona „wychowania wychowawcy" jest u nas lepiej zorganizowana niż na uniwersytecie, który cofnął się nawet w tej dziedzinie w stosunku do 20-lecia, w którym posiadał specjalne studium pedagogiczne. [...] Obecnie nasi absolwenci są coraz lepiej przygotowani do zawodu. Uczelnia daje im nie tylko przygotowanie naukowo-dydaktyczne, ale też tak ważny dziś wysoki poziom wyrobienia politycznego ${ }^{40}$.

Argumentowano, że uniwersytety musiały się zająć kształceniem kadr na potrzeby całej gospodarki, kształcenie zaś nauczycieli zeszło na plan dalszy, a co za tym idzie, ustawał dopływ kandydatów na nauczycieli szkół średnich z uniwersytetów: „Stąd WSP, które pierwotnie miały kształcić wysokokwalifikowanych nauczycieli szkół podstawowych, po uzyskaniu uprawnień szkół akademickich, po przebudowie

37 Ibidem.

${ }^{38}$ Ibidem.

${ }^{39}$ Po wojnie Studium Pedagogiczne było mocno krytykowane, jako nieprzygotowujące właściwie absolwentów do pracy nauczyciela. Łatwość zdobycia posady skutkowała też tym, że absolwenci UJ nie uczęszczali na zajęcia do studium, od razu znajdując zatrudnienie w szkole. $80 \%$ absolwentów podejmowało pracę bez przygotowania pedagogicznego. Ministerstwo Oświaty stopniowo ograniczało liczbę wykładów. W 1952 r. wprowadzono zajęcia dydaktyczne bezpośrednio w toku studiów. Studium Pedagogiczne przestało istnieć. Por. Kronika Uniwersytetu Jagiellońskiego za lata akademickie 1945/19461955/1956, s. 78; R. Dutkowa, Studium Pedagogiczne UJ 1921-1952, „Przegląd Historyczno-Oświatowy", R. XI, 1968, nr 4, s. 468.

${ }^{40}$ Archiwum Uniwersytetu Pedagogicznego w Krakowie (dalej: AUP), Protokoły z posiedzeń Senatu WSP, t. 1, Protokół z posiedzenia Senatu WSP w Krakowie z 29 II 1956 r. 
planów i programów studiów podjęły się kształcenia nauczycieli do szkół średnich ogólnokształcących"41.

Jak wspomina Andrzej Kozanecki, który w WSP pełnił funkcję I sekretarza KU $\mathrm{PZPR}^{42}$, na WSP temat połączenia z UJ pojawiał się już w 1953 i 54 roku.

Mówiło się nie o likwidacji, ale właśnie o połączeniu. Na WSP jednak uważano to za próbę likwidacji uczelni. Już w 1955 r. zlikwidowano w krakowskiej WSP fizykę, przenosząc ją do Opola. Żałowaliśmy tego, bowiem fizyka była silna (opierała się o naukowców z AGH) i chcieliśmy ją rozwijać. Tymczasem co chwilę pojawiały się głosy, że trzeba uczelnie łączyć, integrować, że podniesie się poziom, że wzmocni się zdolność dydaktyczną UJ. Pokazywano dwustronne korzyści ${ }^{43}$.

Rok 1956 przyniósł duże zmiany w szkolnictwie wyższym w Polsce. Zanim jednak doszło do październikowych przemian i przywrócenia autonomii uniwersyteckiej, Uniwersytet Jagielloński stanął przed szansą wzmocnienia swojej pozycji. Uczelnia, którą po II wojnie światowej dotkliwie dotknęły pomysły komunistycznych władz, pozbawiona została kilku wydziałów, które przekształciły się w samodzielne uczelnie. UJ stracił wielu pracowników naukowych i studentów, pomijany był w rozdziale pieniędzy na inwestycje. Szansą na poprawę sytuacji mogło być - zaproponowane na początku 1956 roku przez komunistyczne władze - włączenie w struktury uczelni Wyższej Szkoły Pedagogicznej. Jednak krakowska WSP, placówka, która powstała zaledwie 10 lat wcześniej, ale wykształciła swoje struktury i miała swoje ambicje, nie zamierzała się poddawać i postanowiła walczyć o swoją samodzielność.

Uniwersytet Jagielloński wkraczał w rok 1956 w nie najlepszej kondycji. Ograniczenie autonomiczności, wydzielenie kilku wydziałów, zmniejszenie liczby studentów i pracowników prowadziło do marginalizacji uniwersytetu. W dodatku można się było obawiać, że w przyszłości rosnąć będzie konkurencja ze strony nowego podmiotu - Wyższej Szkoły Pedagogicznej.

Fala odwilży przyniosła też większą swobodę w szukaniu nowych rozwiązań organizacyjnych w szkolnictwie. Stąd wzięły się oficjalne już głosy o konieczności likwidacji dwutorowości kształcenia nauczycieli. Argumentowano, że uniwersytety lepiej przygotowują nauczycieli, mają lepszą kadrę i bazę, WSP kształcą zaś słabo. Władze (w postaci Ministerstwa Oświaty oraz Ministerstwa Szkolnictwa Wyższego) zaproponowały likwidację wyższych szkół pedagogicznych w miastach uniwersyteckich, a więc w Łodzi, Warszawie i w Krakowie, a pozostawienie tych w Gdańsku i Katowicach ${ }^{44}$. WSP przyjęły taką propozycję chłodno, przedstawiając swoją interpretację powodów, dla których dąży się do likwidacji szkół:

${ }^{41}$ J. Jarowiecki, op. cit., s. 5.

${ }^{42}$ KU PZPR - Komitet Uczelniany Polskiej Zjednoczonej Partii Robotniczej.

${ }_{43}$ Relacja Andrzeja Kozaneckiego w zbiorach Wandy Łuczak. Przeniesienie fizyki związane było z decyzją Ministerstwa Oświaty, podjętą w 1955 r., by kierunki niedysponujące zapleczem badawczo-naukowym oraz kadrą likwidować lub przenosić. Por. R. Grzybowski, Wyższe szkoły..., s. 120.

44 PWSP (później WSP) w Łodzi powstała w 1946 r. Uczelnia zaczynała od 37 studentów, a w ostatnim, 1956 r. sięgała już prawie 1800 studentów zaocznych i stacjonarnych. Por. B. Baranow ski, K. Baranow ski, Trudne lata Uniwersytetu Łódzkiego (1949-1956), Łódź 1990, s. 141 i 173. 
Z chwilą uzyskania praw do nadawania stopni magisterskich, wyższe szkoły pedagogiczne wyrosły, w opinii tych, którzy nie zdawali sobie sprawy z kadrowej sytuacji szkolnictwa, ze stojących przed nimi zadań ogólno-oświatowych [sic!] - do roli niebezpiecznych i niepotrzebnych konkurentów uniwersytetów, dublujących ich rolę. Rozpoczął się atak na samą koncepcję szkół, powstały plany likwidacji, [...] tak wielką była niecierpliwość tych, którzy młode, nieokrzepłe organizmy porównywali ze stanem kadrowym i osiągnięciami naukowymi przodujących uniwersytetów, wyciągając stąd jakże łatwe, a przez to nic nie znaczące wnioski ${ }^{45}$.

W 1956 roku debata o przyszłości WSP weszła w fazę decydującą ${ }^{46}$. W prasie była mowa o planach łączenia uczelni czy raczej wchłonięcia wyższych szkół pedagogicznych przez uniwersytety ${ }^{47}$. Na krakowskiej WSP zdawano sobie sprawę z zagrożenia i postanowiono mu przeciwdziałać. Proponowano rozpoczęcie kampanii prasowej i prezentację osiągnięć, chciano zdopingować ludzi spoza WSP do pozytywnego wypowiadania się na temat uczelni. Liczono na wsparcie instancji partyjnych:

W związku z tendencjami do zlikwidowania WSP postanowiono wysłać do KC PZPR oraz do Ministerstwa Oświaty specjalny memoriał ilustrujący dorobek i funkcję naszej Uczelni w zakresie kształcenia naukowego, dydaktycznego i pedagogicznego oraz wychowania politycznego przyszłych nauczycieli ${ }^{48}$.

Andrzej Kozanecki, I sekretarz KU PZPR przy WSP, deklarował: „Egzekutywa KW jest zdecydowanie przeciw likwidacji WSP, jeśli kwestia nie będzie regulowana odgórnie, to KW regulować będzie tę kwestię po naszej linii"49.

W kwietniu 1956 roku na polecenie władz zorganizowano na UJ spotkanie, na którym przedstawiciele Ministerstwa Szkolnictwa Wyższego, UJ i WSP mieli omówić sprawę połączenia. Już wymiana korespondencji przed konferencją nie wróżyła powodzenia. Jeśli na UJ myślano, że pracownicy WSP - w zdecydowanej większości wywodzący się czy dalej pracujący na UJ - będą za połączeniem uczelni, to głęboko się mylono. Zanim doszło do pierwszego spotkania, Senat WSP zaprotestował przeciwko formie zaproszenia na konferencję - zaproszenie wystosował bowiem UJ, a nie Ministerstwo Oświaty. Władze uczelni uznały to za obraźliwe i stwierdziły, że przedstawiciele WSP nie wezmą udziału w konferencji, o ile przedtem na uczelnię nie przybędzie przedstawiciel Ministerstwa Oświaty i nie przedstawi ministerialnego stanowiska co do połączenia. W dyskusji stwierdzono, że proponowane połączenie nie jest korzystne ani dla studentów, ani dla personelu, a likwidacja jest przedwczesna,

45 Wyższa Szkoła Pedagogiczna w Krakowie..., s. 7.

${ }^{46}$ Dyskusja o dalszym istnieniu krakowskiej WSP zbiegła się z przypadającymi na rok 1956 obchodami dziesięciolecia uczelni. Chciano pokazać dorobek uczelni, sukcesy jej absolwentów. Powołano komitet honorowy obchodów. Obchody jubileuszu miały miejsce 21-22 XII 1956 r. AUP, Protokoły z posiedzeń Senatu WSP, t. 1, Protokół z posiedzenia Senatu WSP w Krakowie z 23 XI 1955 r.

${ }^{47}$ Debata toczyła się także na V Krajowym Zjeździe Delegatów ZZNP, gdzie zarząd związku rzucił hasło przejmowania zadań kształcenia nauczycieli przez uniwersytety. Krytykowano coraz powszechniej dwutorowość kształcenia. „Życie Szkoły Wyższej” 1955, nr 12, s. 12.

${ }_{48}$ AUP, Protokoły z posiedzeń Senatu WSP w Krakowie, t. 1, Protokół z posiedzenia Senatu WSP w Krakowie z 29 II 1956 r.

${ }^{49}$ ANKr, KU PZPR przy WSP w Krakowie, 29/2435/25, Protokół z posiedzenia KU PZPR z 8 III $1956 \mathrm{r}$. 
bo uniwersytety nie są przygotowane do objęcia funkcji WSP ${ }^{50}$. Zgodnie z tym stanowiskiem 6 kwietnia 1956 roku rektor WSP prof. Zygmunt Mysłakowski ${ }^{51}$ odpisał do rektora UJ prof. Teodora Marchlewskiego:

Z zaproszenia nie będziemy mogli skorzystać przed otrzymaniem potrzebnych dyrektyw z Ministerstwa Oświaty jako naszej władzy nadrzędnej. Dyrektywy te otrzymamy na posiedzeniu Senatu WSP z zapowiedzianym udziałem przedstawicieli Ministerstwa w dniu $10 \mathrm{bm}$. w godzinach rannych. Na posiedzeniu tym zostanie również powzięta decyzja o naszym ewentualnym udziale w konferencji na Uniwersytecie Jagiellońskim ${ }^{52}$.

Rektor Marchlewski odpowiedział:

Powyższa konferencja jest zwołana przez Ministerstwo Szkolnictwa Wyższego i Ministerstwo Oświaty i wezmą w niej udział zarówno przedstawiciele Ministerstwa Szkolnictwa Wyższego jak i Ministerstwa Oświaty, powołani do tego celu przez Prezydium Rządu. Wobec tego na konferencji powyższej będzie mógł Pan Kolega bezpośrednio zapoznać się ze stanowiskiem Ministerstwa Oświaty jako rektor PWSP, a ze stanowiskiem Ministerstwa Szkolnictwa Wyższego - jako prof. $\mathrm{UJ}^{53}$.

9 kwietnia władze UJ spotkały się z przedstawicielami ministerstw, gdzie próbowano wstępnie uzgodnić kwestie przyłączenia. Przedstawiciele uniwersytetu wyrażali wątpliwości co do sensowności przejmowania studentów zaocznych WSP, co do dziennych proponowano, by przejmować ich etapami, ewentualnie część mogłaby kończyć studia w Katowicach (noszących wówczas nazwę Stalinogrodu) lub w Opolu. Co do pracowników, zgodnie z zamysłami Ministerstwa Oświaty przedstawiciele UJ widzieli ich przeniesienie do Opola lub Katowic - jedynie najlepsi mogliby dołączyć do UJ. Ogólnie uważano, że poziom zarówno kadry, jak i studentów na WSP jest bardzo niski i wyrównanie ich poziomu do poziomu UJ będzie trudne ${ }^{54}$. Przedstawiciel Ministerstwa Szkolnictwa Wyższego poinformował zebranych, że konferencje na podobny temat odbyły się już w Łodzi i Warszawie i dały pozytywne rezultaty:

Stanowisko resortu jest przeciwne dwutorowości w kształceniu nauczycieli. Poziom uczniów szkoły średniej jest coraz gorszy. Wpływa na to poziom absolwentów itd. - znane zamknięte koło. Do tego dochodzą wiadomości o faworyzowaniu absolwentów PWSP przez władze szkolne, podległe Ministerstwu Oświaty ${ }^{55}$.

Inny przedstawiciel ministerstwa dodawał, że uczelnie korzystnie byłoby połączyć, bo obie mają trudne warunki lokalowe. Prorektor UJ prof. Kazimierz Lepszy przyznawał: ,[...] istnieje znaczna różnica w merytorycznej stronie wychowywania młodzieży w obu uczelniach; w PWSP przeważa pedagogizacja i to stanowi argument tej uczelni

${ }^{50}$ AUP, Protokoły z posiedzeń Senatu WSP w Krakowie, t. 1, Protokół z posiedzenia Senatu WSP w Krakowie z 6 IV 1956 r.

${ }^{51}$ Prof. Zygmunt Mysłakowski był równocześnie profesorem UJ, kierownikiem Katedry Pedagogiki.

${ }^{52}$ AUP, t. 122/61, Zjazdy i konferencje 1948-1961.

${ }^{53}$ Ibidem.

${ }_{54}$ Przebieg dyskusji na konferencji por. AUJ, S IV R 11, Przebieg konferencji wstępnej w sprawie połączenia PWSP w Krakowie z Uniwersytetem Jagiellońskim z 9, 10, 11 IV 1956 r.

${ }^{55}$ Ibidem. 
przeciw studium uniwersyteckiemu" ${ }^{\prime 5}$. Informował o stanowisku Ministerstwa Szkolnictwa Wyższego, iż nie wszyscy studenci WSP muszą przejść na Uniwersytet - część może się przenieść na WSP do Katowic lub Opola. Przekazywał także, że Ministerstwo Oświaty zamierza pracownikami WSP wzmocnić WSP w Opolu i Katowicach, Ministerstwo Szkolnictwa Wyższego zaś godzi się przejąć personel stojący na odpowiednim poziomie naukowym. Prorektor UJ prof. Jan Moszew zaznaczył, że sprawę połączenia należy załatwić od razu, nie etapami, bo WSP broni się przed połączeniem i będzie hamować fuzję. Konkluzją była zgoda władz UJ na przyłączenie WSP. Za konieczne uznano przejęcie całej bazy materialnej, natomiast co do kadry, miało to nastąpić według indywidualnych rozstrzygnięć w porozumieniu z zainteresowanymi katedrami. Przyznawano, że konieczne będzie dopasowanie programów nauczania w zależności od wymogów poszczególnych kierunków studiów uniwersyteckich.

Spotkanie przedstawicieli UJ, WSP i władz oświatowych odbyło się 10 i 11 kwietnia 1956 roku. Wspólnie próbowano wypracować stanowisko w kwestii połączenia uczelni. Wydawało się, że przy akceptacji władz oświatowych sprawa powinna szybko zostać zamknięta. Przedstawiciel Ministerstwa Szkolnictwa Wyższego (K. Wojciechowski) argumentował, że nie chodzi o licytowanie się, która uczelnia jest lepsza, ale o połączenie wysiłków w miastach uniwersyteckich.

Takie postawienie sprawy: rozdzielenie studentów, weryfikacja pracowników, nie mogło się jednak podobać na WSP, dlatego jej pracownicy postanowili bronić się przed połączeniem. Rektor uczelni prof. Zygmunt Mysłakowski krytykował podejście do tematu: „Byłem zdziwiony wybuchem na łamach prasy tego zagadnienia. 2-3 głosów rzeczowych, artykuły raczej przypominają mowy adwokatów - krzyk. Dyskusja to wymiana poglądów, argumentacja, a nie hasła. Usiłowano stworzyć atmosferę, że sprawa jest przesądzona"57. Przypominał, że fuzja to nie tylko młodzież, budynki, wykładowcy. Domagał się zapewnienia, że UJ nie uroni nic z dorobku kształcenia nauczycieli i podkreślał, że młodzież na WSP ma wysoki poziom ideowy. Krytycznie do sprawy połączenia odniósł się przedstawiciel Komitetu Wojewódzkiego PZPR, wskazując, że przy rekrutacji na UJ pochodzenie klasowe nie będzie miało znaczenia, natomiast na WSP - tak. Stwierdził, że absolwenci WSP są staranniej przygotowani do prowadzenia lekcji.

W ostatnim dniu konferencji przedstawiciele WSP dali jasno do zrozumienia, że nie zgadzają się na połączenie. Docent Wincenty Danek, dziekan Wydziału Zaocznego WSP (późniejszy rektor), stwierdził:

[...] do pewnego czasu nie było punktów tarcia, dopóki PWSP nie przeszła na system magisterski. Przedtem nie dyskutowano. Gdy staliśmy się współrzędnym partnerem, gdy zaistniała ciasnota na rynku nauczycielskim, wtedy staliśmy się tymi, którzy ,przeszkadzają”. To jest geneza planów jednoczenia. Sprawa docierała do nas w sposób uwłaczający godności szkoły. Mówiono ciągle o likwidacji jakiejś tam ,szkółki” - nie o połączeniu. To uwłaczało nam. [...] W M.O. [Ministerstwie Oświaty - W.Ł.] powiedziano nam, że nie ma przeludnienia w nauczycielstwie. Dlatego uważamy, że jesteśmy potrzebni. [...] Konieczności obecnego łączenia nie widzimy ${ }^{58}$.

\footnotetext{
56 Ibidem.

57 Ibidem.

58 Ibidem.
} 
Doc. Danka wsparł Andrzej Kozanecki, szef uczelnianej organizacji partyjnej na WSP, który stwierdził:

[...] różnice pomiędzy UJ a PWSP istnieją. Większość (pracowników WSP - WŁ) to nauczyciele, działacze oddziałów. Taka kadra ma możliwość przekazywania swych doświadczeń i swego warsztatu. [...] WSP nie mają tradycji, ale mają osiągnięcia. [...] Klimatu nauczycielskiego w Uniwersytecie nie ma, absolwenci UJ nie realizują nakazów pracy do szkót ${ }^{59}$.

Z kolei tow. Bogdan Kędziorek (I sekretarz KU PZPR przy UJ) wskazywał, że połączenie zniwelowałoby problem dwuetatowości, wielu bowiem naukowców z UJ pracuje też na WSP, co powoduje zaniedbywanie obowiązków (wskazał tu na prof. Mysłakowskiego).

Konferencja połączeniowa nie przyniosła spodziewanych rezultatów. Wobec stanowczego sprzeciwu WSP nie doszło do połączenia uczelni. Inaczej potoczyły się losy WSP w Łodzi i Warszawie. 18 czerwca 1956 roku Rada Ministrów przyjęła uchwałę w sprawie włączenia Wyższej Szkoły Pedagogicznej w Warszawie do Uniwersytetu Warszawskiego oraz WSP w Łodzi do Uniwersytetu Łódzkiego ${ }^{60}$.

Dlaczego WSP nie została połączona z UJ? Z pewnością władze UJ nie zaangażowały się w pełni w sprawę połączenia, dostrzegając w nim więcej kłopotów niż zalet. Podnoszono kwestię studentów i pracowników nieodpowiadających poziomowi UJ, nie skupiano się na możliwości powiększenia bazy lokalowej i podniesienia rangi uczelni, liczby studentów oraz zmonopolizowania kształcenia nauczycieli w Krakowie. W sumie więc władze UJ nie doceniły tematu.

Badacz historii wyższych szkół pedagogicznych Romuald Grzybowski podaje, że władze po energicznych protestach pracowników krakowskiej WSP postanowiły odłożyć włączenie o rok i dzięki tej zwłoce uczelnia przetrwała ${ }^{61}$. Z pewnością pomógł ostry sprzeciw i kontrakcja podjęta przez pracowników WSP. Zaważyć mogła też osoba rektora WSP, prof. Zygmunta Mysłakowskiego, który cieszył się dużym poważaniem w kręgach władzy. Mysłakowski jeszcze w czasie wojny sympatyzował z PPR, potem przystąpił do PZPR. W czasie okupacji był członkiem Konspiracyjnej Wojewódzkiej Rady Narodowej, a po wojnie działał w Towarzystwie Przyjaźni Polsko-Radzieckiej oraz w Klubie Inteligencji Demokratycznej „Kuźnica”62.

${ }^{59}$ Ibidem.

${ }^{60}$ Nie rozegrało się to bez oporów: 22 IV 1956 r. odbyła się akcja protestacyjna części pracowników łódzkiej WSP. Władze UŁ zapewniły jednak, że wszyscy pracownicy WSP zostaną zatrudnieni na uniwersytecie. W środowisku łódzkim fakt przyłączenia WSP do uniwersytetu nie był oceniany jednoznacznie. $Z$ jednej strony cieszono się, że przybędą budynki, sprzęt, etaty, z drugiej uznawano to za „zaśmiecanie” uczelni i przysparzanie kłopotów. Por. B. Baranow ski, K. Baranow ski, op. cit., s. 165.

${ }^{61}$ R. Grzybowski, Wyższe szkoły..., s. 141. Informację tę podają Bohdan Baranowski i Krzysztof Baranowski, badacze dziejów Uniwersytetu Łódzkiego, nie ma jednak dowodów, by były takie ustalenia. Wydaje się raczej, że w środowisku akademickim krążyła taka pogłoska. Por. B. Baranowski, K. Baranowski, op. cit., s. 180.

${ }^{62}$ Jerzy Jarowiecki wspominał, że wraz z rektorem Mysłakowskim oraz kilkoma innymi reprezentantami WSP został zaproszony na UJ, by „[...] dopełnić formalności związanych z przyłączeniem. [...] Usłyszeliśmy pytanie, czy jesteśmy gotowi do przekazania dokumentów. Prof. Mysłakowski poruszał się o kulach. Usłyszawszy to pytanie, oparł się o stół, położył na nim jedną kulę, później drugą i uderzył 
Niebagatelną rolę mogło też odegrać oblicze młodej uczelni, której pracownicy i studenci wydawali się w dużo większym stopniu niż osoby związane z UJ akceptować nową, powojenną rzeczywistość. WSP mogła być przeciwwagą dla konserwatywnego uniwersytetu. Jak wspomina Kozanecki:

[...] podkreślaliśmy, że kształcimy ludzi zaangażowanych ideowo. Wszędzie mówiono, że szkoła potrzebuje nauczyciela nastawionego prospołecznie, chcącego oddziaływać na innego człowieka, na rzeczywistość. Wychowanie prospołeczne stało u nas wyżej. Argumentowano i tym, że WSP w większym stopniu skupia młodzież chłopską i robotniczą (a bardzo mało osób inteligenckiego pochodzenia) ${ }^{63}$.

O ile na UJ jesienią 1953 roku organizacja partyjna liczyła 415 członków i kandydatów, w tym 47 pracowników nauki (przy 3461 studentach i 398 pracownikach naukowych), o tyle zaangażowanie w pracę partyjną na WSP było większe. W 1955 roku POP PZPR ${ }^{64}$ przy WSP chciała utworzyć dodatkowe oddziałowe organizacje partyjne, bo nastąpił znaczny wzrost liczby członków PZPR: należało do niej już 150 osób, a było też kolejnych 30 kandydatów ${ }^{65}$. W styczniu 1956 roku organizacja partyjna mogła pochwalić się już 201 członkami i kandydatami ${ }^{66}$. Taka liczba przy 783 studentach i 86 pracownikach naukowych była imponująca. Władze uczelni deklarowały jasno: „Chcemy wychować przyszłego nauczyciela, czynnego współtwórcę przeobrażeń społecznych zmierzających ku socjalizmowi, człowieka o racjonalistycznym sposobie myślenia i laickim poglądzie na świat” ${ }^{\prime 67}$.

nimi z całej siły. Nie życzył sobie takich rozmów. Był profesorem UJ, ale przede wszystkim był rektorem sprawnie działającej szkoły wyższej i nie widział powodu, dla którego należałoby ją włączyć w struktury Uniwersytetu Jagiellońskiego". Taką scenę zapamiętał też Andrzej Kozanecki, ówczesny sekretarz POP PZPR przy WSP: „Pamiętam, że bardzo ważne spotkanie w tej sprawie odbyło się w 1956 r. w auli uniwersytetu. UJ reprezentował rektor T. Marchlewski, WSP ja (jako I sekretarz POP WSP) z rektorem Z. Mysłakowskim i Stefanem Jędrychowskim, dyr. administracyjnym. Rektor Marchlewski perorował, że trzeba się połączyć, że będą korzyści, ludzie WSP zyskają większe możliwości rozwoju naukowego, a do UJ wniesione zostaną pewne dydaktyczne wartości. Na spotkaniu powiedzieliśmy jasno, że połączenie uczelni jest wykluczone. Mysłakowski zezłościł się i laską walił w oparcie krzeseł w auli. Była spora awantura". Por. Rozmowy jubileuszowe, Kraków 2011, s. 67; oraz relacja A. Kozaneckiego w zbiorach W.Ł. Postać Zygmunta Mysłakowskiego A. Kozanecki wspomina tak: „Z. Mysłakowski (równocześnie prof. UJ) był wtedy w Krakowie najwybitniejszym pedagogiem, miał ogromny autorytet, a swoimi lewicowymi zapatrywaniami i poglądami umocnił swoją pozycję. Aczkolwiek w latach 50. (w drugiej połowie) odchodził z pozycji marksistowskich”. Por. Relacja A. Kozaneckiego w zbiorach W.Ł.; I. Szaniawski, Zygmunt Myslakowski 1890-1971, „Ruch Pedagogiczny”, R. 46, 1972, nr 2, s. 238; S. Baścik, Zygmunt Mysłakowski (1890-1971), „Nowa Szkoła” 1972, nr 1, s. 28; a także G. Michalski, Udziat Zygmunta Mystakowskiego w reorientacji ideowo-programowej ZNP w pierwszych latach po II wojnie światowej [w:] Oświata, wychowanie, kultura fizyczna..., red. R. Grzybowski. W tej ostatniej rozprawie przedstawiony został udział Z. Mysłakowskiego w zdominowaniu przez PPR i PPS Związku Nauczycielstwa Polskiego.

${ }^{63}$ Relacja A. Kozaneckiego w zbiorach W.Ł.

${ }^{64}$ POP PZPR - Podstawowa Organizacja Partyjna Polskiej Zjednoczonej Partii Robotniczej.

${ }^{65}$ ANKr, KU PZPR przy WSP w Krakowie, 29/2435/77, Uchwała egzekutywy POP PZPR przy WSP z 21 II 1955 r.

${ }^{66}$ Dziesięciolecie Wyższej Szkoty Pedagogicznej ..., s. 38.

${ }^{67}$ W. Danek, Zagadnienie kształcenia nauczycieli w świetle nowych tendencji oświatowych, „,Rocznik Naukowo-Dydaktyczny WSP w Krakowie" 1957, z. 6, s. 7. 
Sprawa likwidacji WSP pojawiała się w kolejnych latach sporadycznie jako ewentualny postulat UJ. W „Wytycznych dla prac nad strukturą Uniwersytetu Jagiellońskiego" zapisano, że niezbędne jest wznowienie zlikwidowanych poprzednio kierunków, katedr i zakładów, pojawił się też postulat zlikwidowania Wyższej Szkoły Pedagogicznej i wchłonięcia jej przez uniwersytet, co pozwoliłoby na lepsze przygotowywanie kadr nauczycielskich ${ }^{68}$. Krakowska WSP także Jednak przekonywała o swej niezbędności. W 1957 roku Wincenty Danek (ówczesny rektor WSP) thumaczył:

Uniwersytety [...] nigdy nie starały się przystosować swych programów naukowych do potrzeb przyszłych nauczycieli. Kształciły w zasadzie naukowców, a fakt, że najmniej 90 procent absolwentów odnośnych wydziałów uniwersyteckich szło do szkół, jak gdyby nie był dostrzegany. Nauczyciel był i jest produktem dodatkowym, o ile nie odpadkowym szkoleniowej pracy uniwersytetów ${ }^{69}$.

Sumował także decyzje władz z 1956 roku o likwidacji dwóch WSP:

Niemniej jednak w naturalnym rozwoju sytuacji, z chwilą zapełnienia się luk kadrowych w szkole średniej, musiało przyjść do zakwestionowania racji bytu wyższych szkół pedagogicznych. Używane przy tym argumenty pozbawione były jednak w znacznej większości racjonalnych podstaw. Nie myślano o właściwym wyzyskaniu niezaprzeczalnego ich dorobku, o skorzystaniu z ich doświadczeń. W rezultacie połączono w 1956 r. WSP w Warszawie i Łodzi z uniwersytetami, ostały się zaś szkoły w Krakowie, Katowicach, Opolu i Gdańsku ${ }^{70}$.

Wydaje się, że wchłonięcie WSP było najbardziej realną możliwością wzmocnienia UJ w roku 1956. Szansa była, bowiem w Warszawie i w Łodzi władze poparły i doprowadziły do likwidacji WSP. W Krakowie natomiast do tego nie doszło i o sprawie dość szybko zapomniano. Rok 1956 przyniósł bowiem nowe wydarzenia i nowe wyzwania.

\section{BIBLIOGRAFIA}

\section{Archiwa}

Archiwum Uniwersytetu Jagiellońskiego

Archiwum Uniwersytetu Pedagogicznego

Protokoły z posiedzeń Senatu WSP, t. 1.

Zjazdy i konferencje 1948-1961. t. 122/61.

Archiwum Narodowe w Krakowie

KU PZPR przy WSP w Krakowie, sygn. 29/2435/25, 29/2435/77

${ }^{68}$ AUJ, S IV SO g 2, Protokoły posiedzeń Senatu UJ z lat 1953-59, Protokół z posiedzenia Senatu UJ z 8 IV 1959 r.

${ }^{69}$ W. Danek, op. cit. s. 5.

${ }^{70}$ Ibidem. 


\section{Akty prawne}

Dekret Rady Ministrów z dnia 28 X 1947 r. o organizacji nauki i szkolnictwa wyższego (Dz.U. 1947, nr 66, poz. 415).

Ustawa z dnia 15 XII 1951 r. o szkolnictwie wyższym i pracownikach nauki (Dz.U. 1952, nr 6, poz. 38).

Rozporządzenie Rady Ministrów z dnia 24 X 1949 r. w sprawie założenia akademii lekarskich w Warszawie, Krakowie, Poznaniu, Lublinie, Łodzi i Wrocławiu (Dz.U. 1949, nr 58, poz. 450).

\section{Artykuły prasowe}

Absolwenci uniwersytetów - nauczycielami szkół średnich, „Życie Szkoły Wyższej” 1956, nr 2, s. 77-78.

Problem WSP i uniwersytetów, „Głos Nauczycielski”, 1 IV 1956, nr 14, s. 1.

Szkolnictwo wyższe u progu planu 5-letniego, „Życie Szkoły Wyższej” 1956, nr 2, s. 7.

Wroczyński R., Uniwersytet czy wyższe szkoły pedagogiczne, „Życie Szkoły Wyższej” 1956, nr 3, s. 42-46.

„Głos Nauczycielski”, 11 III 1956, nr 11.

„Życie Szkoły Wyższej” 1955, nr 12.

\section{Relacje}

Relacja A. Kozaneckiego w zbiorach W.Ł.

\section{Opracowania}

Banach A.K., Dybiec J., Stopka K., Dzieje Uniwersytetu Jagiellońskiego, Kraków 2000.

Baranowski B., Baranowski K., Trudne lata Uniwersytetu Łódzkiego (1949-1956), Łódź 1990.

Baścik S., Zygmunt Mysłakowski (1890-1971), „Nowa Szkoła” 1972, nr 1.

Chodakowska J., Rozwój szkolnictwa wyższego w Polsce Ludowej w latach 1944-1951, Wrocław 1981.

Danek W., Zagadnienie kształcenia nauczycieli w świetle nowych tendencji oświatowych, „Rocznik Naukowo-Dydaktyczny WSP w Krakowie” 1957, z. 6.

Dutkowa R., Studium Pedagogiczne UJ 1921-1952, „Przegląd Historyczno-Oświatowy”, R. XI, 1968, nr 4.

Dziesięciolecie Wyższej Szkoły Pedagogicznej w Krakowie 1946-1956, red. W. Danek, Kraków 1957.

Grzybowski R., Geneza wyższych szkół pedagogicznych i ich rozwój organizacyjny w latach 1946-1949, „Biuletyn Historii Wychowania” 2000, nr 1-2.

Grzybowski R., Wyższe szkoły pedagogiczne w Polsce w latach 1946-1956, Toruń 2010. Grzybowski S., Wspomnienia, Kraków 1999.

Hübner P., Polityka naukowa w Polsce w latach 1944-1953. Geneza systemu, Wrocław 1992. 
Historia nauki polskiej, t. X, 1944-1989, cz. 1: Warunki rozwoju nauki polskiej, państwo $i$ społeczeństwo, cz. 2: Instytucje, cz. 3: Idee i praktyka, red. L. Zas ztow t, J. Schiller- Walicka, Warszawa 2015.

Jarowiecki J., Kształcenie nauczycieli w wyższych szkołach pedagogicznych, WarszawaKraków 1967.

Kałuski S., W sprawie systemu kształcenia nauczycieli szkót średnich, „Życie Szkoły Wyższej" 1956, nr 1.

Krasiewicz B., Odbudowa szkolnictwa wyższego w Polsce Ludowej w latach 1944-1948, Wrocław 1976.

Kronika Uniwersytetu Jagiellońskiego za lata akademickie 1945/1946-1955/1956, Kraków 1971.

Łuczak W., Między autonomia a zależnościa. Przygotowania do obchodów jubileuszu 600-lecia Uniwersytetu Jagiellońskiego, praca doktorska obroniona na Wydziale Historycznym UJ w 2017 r., Kraków 2017.

Michalski G., Udział Zygmunta Mysłakowskiego w reorientacji ideowo-programowej ZNP w pierwszych latach po II wojnie światowej [w:] Oświata, wychowanie, kultura fizyczna w rzeczywistości społeczno-politycznej Polski Ludowej (1945-1989), red. R. Grzybowski, Torun 2004.

Oświata, wychowanie, kultura fizyczna w rzeczywistości społeczno-politycznej Polski Ludowej (1945-1989), red. R. Grzybowski, Torun 2004.

Państwowe Pedagogium i Szkoła Ćwiczeń w Krakowie. Z tradycji ksztatcenia nauczycieli, oprac. J. Krukowski, B. Morawska-Nowak, Kraków 2011.

Politechnika Warszawska, red. K. Kolbiński, Warszawa 1965.

Polski Słownik Biograficzny, t. XIX, red. E. Rostworowski, Wrocław [etc.] 1974.

Rozmowy jubileuszowe, Kraków 2011.

Rutkowski T.P., Nauki historyczne w Polsce 1944-1970. Zagadnienia polityczne i organizacyjne, Warszawa 2007.

Serczyk J., Uniwersytety polskie w latach stalinizmu (esej wspomnieniowy), „Czasy Nowożytne" 1999, t. VI.

Szaniaw ski I., Zygmunt Mysłakowski 1890-1971, „Ruch Pedagogiczny”, R. 46, 1972, nr 2.

Sześćsetlecie medycyny krakowskiej. W sześćsetlecie Uniwersytetu Jagiellońskiego, t. 2: Historia katedr, red. nauk. L. Tochowicz [et al.], Kraków 1964.

Szłapczyński J.K., Zarząd szkoła wyższa w Polsce Ludowej, Warszawa 1968.

Tabaka Z., Z dziejów Wyższej Szkoty Pedagogicznej w Krakowie (1946-1961) [w:] Ksztatcenie nauczycieli w Wyższej Szkole Pedagogicznej (Konferencja naukowa ku uczczeniu 15-lecia Wyższej Szkoły Pedagogicznej w Krakowie 1946-1961), red. W. Gałecki, Kraków 1962.

Tymowski J., Organizacja szkolnictwa wyższego w Polsce, Warszawa 1980.

Wiloch T., Radziecki system oświatowo-wychowawczy, Warszawa 1962.

Wyższa Szkoła Pedagogiczna w Krakowie w pierwszym piętnastoleciu rozwoju 1946-1961, red. M. Tyrowicz [et al.], Kraków 1965. 